\title{
A MICROSATELLITE LIBRARY FOR Carica papaya L. CV. SUNRISE SOLO ${ }^{1}$
}

\author{
SILVIA CORREA SANTOS², CARLOS RUGGIERO³, CRISTINA LACERDA SOARES PETRAROLHA SILVA ${ }^{4}$, ELIANA \\ GERTRUDES MACEDO LEMOS ${ }^{5}$
}

\begin{abstract}
In experimental areas of the Education and Researches Ilha Solteira and Jaboticabal UNESP/Campus farms were selected and tagged 20 hermaphrodite plants and 20 feminine of cultivar Sunrise Solo, Improved Sunrise Solo cv.72/12 and Baixinho of Santa Amália.The seeds origined of the selected fruits were cropped to be analysed the self-pollination efficiency and frequency of the sex in the progenies. After that, samples of the young leaf of the matrix plants were colected for the extration of the DNA. It was built five library enriched of microsatellite sequencies, using probes $(\mathrm{TCA})_{10},(\mathrm{TC})_{13},(\mathrm{GATA})_{4},(\mathrm{CAC})_{10} \mathrm{e}(\mathrm{TGAG})_{8}$. It was possible the development of the primers only in the library that has utilized the probe (TCA) ${ }_{10}$ This probe allowed the design of 32 primer pairs. From these, 31 presented pattern of unique band in agarose Metaphor and in acrilamide. For primer S36 were observed 2 bands, but with no polymorphism to differentiation in the sexual form at papaya tree culture. However, these primers can be tested, in the futures, in the investigation of the others features in segregated populations of this specie and the related species, germoplasm analysis, cultivars identification, parent evolution and molecular markers for the assisted plant breeding programs.
\end{abstract}

Index terms: Carica papaya, sex, microsatellite markers, library.

\section{MARCADORES MICROSSATÉLITES PARA Carica papaya L. CV. SUNRISE SOLO}

RESUMO - Em áreas experimentais das Fazendas de Ensino e Pesquisa da UNESP/Campus de Ilha Solteira e Jaboticabal foram selecionadas e marcadas 20 plantas hermafroditas e 20 femininas dos cultivares Sunrise Solo, Improved Sunrise Solo cv.72/12 e Baixinho de Santa Amália. As sementes provenientes dos frutos selecionados foram plantadas para analisar-se a eficiência da autofecundação e a freqüência dos sexos nas progênies. Posteriormente, amostras de tecido foliar jovem das plantas matrizes foram coletadas para a extração de DNA. Foram construídas cinco

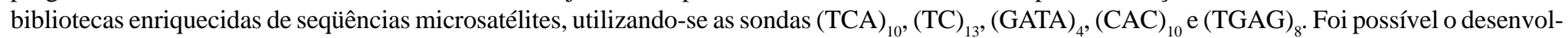
vimento de primers somente com a biblioteca que utilizou a sonda (TCA) ${ }_{10}$. Esta permitiu o desenho de 32 pares de primers. Destes, 31 apresentaram padrão de banda única em agarose Metaphor e em acrilamida. Para o primer S36 foram observadas 2 bandas, mas sem polimorfismo para diferenciação da forma sexual na cultura do mamoeiro. No entanto, estes primers poderão ser testados na investigação de outras características em populações segregantes desta espécie e de espécies afins, análises de germoplasma, identificação de cultivares, evolução parental e marcas em melhoramento assistido.

Termos para indexação: Carica papaya, sexo, marcadores microsatélites, biblioteca.

\section{INTRODUCTION}

Papaya, originally from Central America, probably from southern Mexico, is becoming more important in Brazil (Mendes et al., 1996), which has turned into the biggest producer, with a harvested area, in 1998 , of about 40 thousand hectares, mostly in the states of Bahia and Espírito Santo (Agrianual, 2001).

The culture, however, has technical problems that need to be solved; among them are the health problems, such as mosaic, papaya sticky disease, and mites, among others, as well as problems with its propagation, which has in the sexual reproduction its major system. Moreover, the papaya has male, female and hermaphrodit plants, and due to the greater commercial value of the hermaphrodites plants, it demands that the farmers plant 3 seedlings per planting hole, removing the female at flowering. Even with this procedure, there are left in the field after thinning, about 3 to $8 \%$ of the female plants.

In a search to reduce even more the percentage of female plants, some farmers make a continuous seedling planting, $75 \mathrm{~cm}$ apart from each other, which leads to an additional expense on seeds and seedlings, but allows for a significant reduction in the number of female plants.

For these reasons, lately efforts have been made in order to obtain a method for the early sex determination in papaya seedlings, before they are transplanted in the field. However, no methodology has yet been effective in reaching this goal. It is noteworthy the research done on the characterization of sex in papaya for, with the discovery of a means for sex determination in this culture, the farmer could identify early enough which seedlings were hermaphrodite and remove the female, saving on the investment that would be done in a plant with unknown sex, and reducing the production costs and end price of the fruit for the consumer. Research has been done for the development of an early sex determination method for papaya seedlings. There are molecular markers (RAPD and fAFLP) that differentiate the sexes, but the cost for in field sexing is too high, making such practice unviable. The use of microsatellite markers, associated to sexing in papaya, is yet to be described in the literature.

The microsatellites are more randomly and uniformly dispersed in the genome that the minisatellites, which are generally limited to the telomeres. The instability of the microsatellites results in highly polymorphic, multi-allele markers that are extremely useful in genetic studies. The alleles differ because they present distinct numbers of tandem repetitions, originated from unequal crossing over during meiosis or by strand slippage of the DNA polymerase during duplication of the molecule The microssatellite are highly reproducible and codominant, presenting a high level of polymorphism. There are three families of microsatellites: pure, composed, or interrupted repetitions. In the pure repetitions, the microsatellite loci are formed by a single repeat motif (5' TATTATTATTATTATTATTATTAT 3'); in the composed repetitions, more than one motif make the microsatellite; and in the interrupted repetitions the motifs are separated by nucleotides that do not belong to the repetition unit (Pinto et al., 2001).

Sharon et al. (1992) detected DNA fingerprints in Carica papaya and other species of Carica, by the use of Southern Blot, with probes from minisatellite and microsatellite sequences. Parasnis et al. (1999) observed the absence of the microsatellite sequences (GAA), $(\mathrm{TG})_{10},(\mathrm{CAC})_{5},(\mathrm{GGAT})_{4}$ and (GACA) $)_{4}$ in the genome of 6 cultivars of papaya by Southern Blotting. However, when using the probe (GATA) they found a $5 \mathrm{~Kb}$ band, specific for male plants, indicating a divergence between the chromosomes $\mathrm{X}$ and $\mathrm{Y}$ from papaya. Those authors also mention that the genetic material from papaya have specific differ-

\footnotetext{
${ }^{1}$ (Trabalho 126/2002). Recebido: 04/06/2002. Aceito para publicação: 30/04/2003. Parte da Tese de Doutorado do primeiro autor.

${ }^{2}$ Docente da UFG - Campus Avançado de Jataí/ Centro de Ciências Agrárias. Rod. BR. 364. Km 192 - Zona Rural. Jataí -GO. 75800-000.E-mail: correa@ jatai.ufg.br

${ }^{4}$ Aluna do Curso de Doutorado da UNESP/FCAV.

${ }^{3,5}$ Docentes da UNESP/FCAV
} 
ences between the sexes and, thus, in the differentiation process.

The genes involved in the sex determination of Carica papaya have not yet been identified at the molecular level, that is, there are no known nucleotide sequences of these genes, neither of their protein products.

For these reasons, the present study had as objectives:

-To observe the sex frequency in the progenies originated from self pollinated hermaphrodite plants;

-To make libraries enriched with microsatellite sequences for Carica papaya $\mathrm{L}$;

-To develop microsatellite primers for Carica papaya $\mathrm{L}$.;

-To observe if there are polymorphisms in the hermaphrodite and female Carica papaya plants with the primers tested.

\section{MATERIALSAND METHODS}

\section{Sample collection}

In the experimental areas of the Research and Teaching Farms of UNESP/Campi of Ilha Solteira and Jaboticabal, breeding plants were selected, marking 20 hermaphrodite and 20 female plants from open pollination, of the cultivars "Sunrise Solo" (hermaphrodite plants represented by SH and female plants by SF), "Improved Sunrise Solo cv. 72/12" (IH - hermaphrodites and IF - females) and "Baixinho de Santa Amália" (BH - hermaphrodites e BF - females). Three flower buds of each hermaphrodite plant of the different cultivars were bagged and marked to ensure the self-pollination. Also, flower buds were selected and marked for the female plants. On the three cultivars, the fruits selected from the self-pollinated hermaphrodite and female plants were harvested for the collection of the seeds.

Ten repetitions for each progeny were planted in the Research and Teaching Farms of UNESP/Campus of Ilha Solteira. The efficiency of self-pollination and the sex frequency in the progenies were observed in the field. The sex frequency was evaluated using the Chisquare test at $5 \%$ probability.

Samples of new leaf tissue of the breeder plants selected and of the progenies were collected, cut in small pieces, and macerated with the addition of liquid nitrogen, and stored at $-20^{\circ} \mathrm{C}$. These materials were used for DNA extraction.

\section{Extraction of genomic DNA}

The DNA extraction was done by the Saghai-Maroof et al. (1984) method, in 10 hermaphrodite and 10 female plants of the 3 cultivars mentioned previously.

\section{Determination of microsatellite profiles}

Initial DNA preparation for elaboration of a sub-library - Total DNA was extracted from an hermaphrodite plant of "Sunrise Solo" cultivar. This was digested with the restriction enzyme Sau 3 AI (genomic DNA $100 \mu \mathrm{g}$, Sau3 AI 250 U, buffer (10X) $20 \mu \mathrm{L}$, sterile water Milli Q qsp $200 \mu \mathrm{L}$ ) at $37^{\circ} \mathrm{C}$ for 16 hours. Then, the digested DNA was separated by electrophoresis in a $2 \%$ low melting agarose gel, at $60 \mathrm{~V}$ for approximately 4 hours. Fragments with size varying from 200 to 800 bp were removed and eluted from the gel. After purification of the fragments with the kit Concert Gel Purification (Gibco BRL), the fragments were subjected to a ligation reaction with adapter terminals Short (5' CAG CCT AGA GCC GAA TTC ACC 3') and Long (5' GAT CGG TGAATT CGGCTC TAG GCT G3').

Enrichment of the sub-library - The technique of hybridization with the probes coupled to magnetic beads covered with streptavidine. The DNA ligated to the adaptors was denatured at $95^{\circ} \mathrm{C}$ for $3 \mathrm{~min}$. to be ligated to the beads. Thus the probes (TCA) $)_{10},(\mathrm{TC})_{13},(\mathrm{GATA})_{4},(\mathrm{CAC})_{10}$, $(\mathrm{TGAG})_{8}$, which were biotinilated (100 picomoles $/ \mu \mathrm{L}$ probe, terminal transferase buffer (1X), Biotine 16 dUTP, terminal transferase, sterile water milli $\mathrm{Q}$ for a final reaction of $24 \mu \mathrm{L}$, were used. After hybridization of the probe with the fragments, these were captured by the beads of the kit Streptavidin MagneSphere Paramagnetic Particles - PROMEGA. Amplification of the sub-library - The enriched fragments were amplified by PCR, using a primer (5'-CAGCCTAGAGGCCGAATTCACC-3') complementary to the adapter terminals. The reaction consisted of DNA - $3 \mu \mathrm{L}$, buffer $1 \mathrm{X}$ (20 mM TRIS-HCl, pH 8.4, $50 \mathrm{mM} \mathrm{KCl} \mathrm{-} \mathrm{GIBCO-}$ BRL), $\mathrm{MgCl}_{2} 2.0 \mathrm{mM}$, dNTP $0.4 \mathrm{mM}$, primer $3 \mathrm{mM}$, Taq DNA polymerase $(2.5 \mathrm{U})$ and sterile water for a final volume of $25 \mu \mathrm{L}$. The amplification program consisted of 1 cycle at $95^{\circ} \mathrm{C}$ for 3 min., 25 cycles $\left(94^{\circ} \mathrm{C}\right.$ for 45 $\mathrm{sec}, 56^{\circ} \mathrm{C}$ for $45 \mathrm{sec}, 72^{\circ} \mathrm{C}$ for $2 \mathrm{~min}$.) and $1 \mathrm{cycle}$ at $72^{\circ} \mathrm{C}$ for $7 \mathrm{~min}$.

Cloning of the library - The sub-library was cloned in the vector pGEM$\mathrm{T}$ (Promega) in the site EcoRV. The DNA (sub-library) ligation reaction in the vector pGEMT was: buffer (1X) T4 ligase, pGEMT (50ng), DNA (sub-library), T4 ligase (12U), sterile water milli Q for a final volume of $10 \mu \mathrm{L}$. The reaction was maintained at $4^{\circ} \mathrm{C}$ for 12 hours. The recombinant plasmid was inserted in competent $E$. coli cells line JM109 (Promega) transformed by heat shock, following the cells provider's protocol.

Extraction of plasmid DNA - The plasmid DNA of the transformed clones was extracted by the alkaline lysis.

Sequencing - The amplification reactions for sequencing of the positive inserts were done in $50 \mathrm{ng} / \mu \mathrm{L}$ DNA, primer - 1.6 pmoles $/ \mu \mathrm{l}, 2 \mu \mathrm{L}$ Big-dye terminator (Perkin-Elmer) and $2 \mu \mathrm{L}$ buffer TRIS/ $\mathrm{MgCl}_{2}$ for a final volume of $10 \mu \mathrm{L}$. The universal primers XY3 pUC/M13 (1211) and XY6 pUC/M13 reverse (1201) were used in the PCR reaction. The amplification was done using the following program: $96^{\circ} \mathrm{C}$ for $2 \mathrm{~min} . ; 25 \mathrm{x}$ $\left(96^{\circ} \mathrm{C}\right.$ for $30 \mathrm{sec} . ; 50^{\circ} \mathrm{C}$ for $15 \mathrm{sec}$; $60^{\circ} \mathrm{C}$ for $4 \mathrm{~min}$.) and a final cycle at $4^{\circ} \mathrm{C}$.

After the amplification the material was washed and the samples prepared for application in the gel. The 5\% gel was prepared according to the manufacture's instructions (Perkin-Elmer) using a Long Ranger polyacrilamide solution. The samples were sequenced in the Sequencing Equipment ABI-Prism 377 (Perkin-Elmer). After sequencing each clone was analyzed in the search for the microsatellite sequences.

Design of the Primer - The useful sequences had pairs of primers designed (forward and reverse) flanking the microsatellite regions. The program used was PRIMER DESIGNER version 2.0, and the criteria used for the design were: $20 \mathrm{pb}$ length, $\mathrm{GC}=40$ to $60 \%, \mathrm{TM}=50$ to $65^{\circ} \mathrm{C}$ and absence of hairpin.

PCR Reaction - For the PCR reactions only DNA from the breeding plants of the cultivars "Sunrise Solo", "Improved Sunrise Solo cv. 72/ 12" and "Baixinho de Santa Amália" were used. The PCR reaction consisted of $150 \mathrm{ng}$ DNA, buffer $1 \mathrm{X}$ (20 mM TRIS-HCl, pH 8.4, $50 \mathrm{mM} \mathrm{KCl}$ - GIBCO-BRL), $\mathrm{MgCl}_{2} 2.0 \mathrm{mM}$, dNTP $1 \mu \mathrm{M}$, Taq DNA polymerase $2.5 \mathrm{U}$, Forward and Reverse primers (8 pmoles each) designed from the microsatellite library, sterile $\mathrm{H}_{2} \mathrm{O}$ milli Q sufficient for $25 \mu \mathrm{L}$. The thermocycling reactions were done in the following steps: 1 cycle at $94^{\circ} \mathrm{C}$ for $5 \mathrm{~min} ., 31 \mathrm{cycles}$ at $94^{\circ} \mathrm{C}$ for $2 \mathrm{~min} ., 55^{\circ} \mathrm{C}$ for $30 \mathrm{sec}$. and $72^{\circ} \mathrm{C}$ for $1 \mathrm{~min}$. and, finally 1 cycle at $72^{\circ} \mathrm{C}$ for $4 \mathrm{~min}$. The reaction products were analyzed in $3.5 \%$ metaphor agarose gels containing ethidium bromide $(0.5 \mu \mathrm{g} / \mathrm{mL})$, by electrophoresis in buffer TBE $1 X$ (TRIS $89 \mathrm{mM}$, boric acid $89 \mathrm{mM}$ and EDTA $2.5 \mathrm{mM}$, pH 8.3) (Maniatis et al., 1989) for 4 to 6 hours at $100 \mathrm{~V}$. Also, $8 \%$ polyacrilamide gels without denaturing agents were used (3.5 mL TBE (1X), $7.0 \mathrm{~mL}$ acrilamide $40 \%, 7.0 \mathrm{~mL}$ bis-acrilamide $2 \%, 17.5 \mu \mathrm{L}$ TEMED, $350 \mu \mathrm{L}$ ammonium persulfate at $10 \%$, distilled water for $35 \mathrm{~mL})$ and with denaturing agent $(3.5 \mathrm{~mL}$ TBE $(1 \mathrm{X}), 7.0 \mathrm{~mL}$ acrilamide $40 \%, 7.0 \mathrm{~mL}$ bis-acrilamide $2 \%, 17.5 \mu \mathrm{L}$ TEMED, $350 \mu \mathrm{L}$, ammonium persulfate at $10 \%, 9.6 \mathrm{~g}$ urea, distilled water for $35 \mathrm{~mL}$ ). A $50 \mathrm{bp}$ DNA Ladder was used for sizing because the fragments were small. The polyacrilamide gels were dyed with silver nitrate.

\section{RESULTS AND DISCUSSION}

\section{Sex Frequency}

Table 1 lists the observed frequencies (\%) of female and hermaphrodite plants and the expected frequency for crossings between 
hermaphrodite plants. It is observed that of the 30 analyzed plants, in 18 hermaphrodite and 12 female plants the calculated chi-square (blue highlight) is smaller than the tabulated, that is, the hypothesis that the crossing between hermaphrodite plants yields a proportion of $67 \%$ of hermaphrodite to $33 \%$ female plants is accepted. Thus, in the analysis of the sex frequency, of the 30 hermaphrodite plants, in 18 (60\% of the plants) the proportion 2 (hermaphrodites): 1 (female) $(40 \%$ female) was confirmed. In the 12 hermaphrodite and 18 female plants left, there could be problems with the self-pollination, such as incorrect fixation of the bags that covered the flower buds, fall of the bags, cross pollination with the aid of pollinating agents, among other causes.

TABLE 1 - Sex frequency in the progenies of the self pollinated hermaphrodite plants (H-OF: observed frequency of hermaphrodite plants; F-OF: observed frequency of female plants; CHI-SQ.: calculated chi-square; CHI-SQTAB: chi-square tabulated $\left(\chi^{2} \alpha_{=5 \% ; 1}\right.$ and $\left.\chi^{2} \alpha_{=5 \% ; 30}\right)$

\begin{tabular}{|l|c|c|c|c|}
\hline PLANTS & H-OF(\%) & F-OF(\%) & CHI-SQ.(H) & CHI-SQ.(F) \\
\hline SH17 & 80 & 10 & 2.52 & 16.03 \\
\hline BH21 & 70 & 30 & 0.13 & 0.27 \\
\hline BH6 & 10 & 80 & 48.49 & 66.94 \\
\hline IH21 & 60 & 40 & 0.73 & 1.48 \\
\hline BH22 & 50 & 30 & 4.31 & 0.27 \\
\hline SH12 & 40 & 50 & 10.88 & 8.76 \\
\hline SH6 & 30 & 50 & 20.43 & 8.76 \\
\hline IH17 & 60 & 20 & 0.73 & 5.12 \\
\hline SH16 & 70 & 20 & 0.13 & 5.12 \\
\hline BH2 & 40 & 30 & 10.88 & 0.27 \\
\hline IH19 & 80 & 20 & 2.52 & 5.12 \\
\hline SH3 & 70 & 30 & 0.13 & 0.27 \\
\hline BH14 & 40 & 60 & 10.88 & 22.09 \\
\hline SH22 & 40 & 50 & 10.88 & 8.76 \\
\hline IH16 & 80 & 10 & 2.52 & 16.03 \\
\hline IH6 & 40 & 50 & 10.88 & 8.76 \\
\hline BH25 & 70 & 30 & 0.13 & 0.27 \\
\hline IH13 & 80 & 10 & 2.52 & 16.03 \\
\hline SH7 & 30 & 50 & 20.43 & 8.76 \\
\hline BH9 & 60 & 40 & 0.73 & 1.48 \\
\hline SH19 & 40 & 60 & 10.88 & 22.09 \\
\hline BH17 & 60 & 40 & 0.73 & 1.48 \\
\hline SH9 & 90 & 10 & 7.90 & 16.03 \\
\hline IH23 & 60 & 30 & 0.73 & 0.27 \\
\hline BH18 & 60 & 40 & 0.73 & 1.48 \\
\hline IH10 & 70 & 30 & 0.13 & 0.27 \\
\hline SH11 & 70 & 30 & 0.13 & 0.27 \\
\hline IH9 & 80 & 20 & 2.52 & 5.12 \\
\hline BH23 & 70 & 20 & 0.13 & 5.12 \\
\hline IH14 & 90 & 10 & 7.90 & 16.03 \\
\hline TOTAL & 1790 & 1000 & 24.08 & 0.10 \\
\hline OBS: Expc & & 0 & \\
\hline
\end{tabular}

OBS: Expected freq. of hermaphrodites $=67 \%$ and expected freq. females $=$ 33\%, CHI-SQ.TAB $=3.84$

\section{Construction of the microsatellite library for Carica papaya $\mathbf{L}$. cv. Sunrise Solo}

The construction of libraries for C. papaya cv. Sunrise Solo was successful in all steps. The amplification of the sub-library by PCR was also successful without contamination of the probe during the enrichment of the sub-library or washing of the beads. In the library evaluated with the probe (TCA) ${ }_{10}$ microsatellite sequences were observed, while on the sequencing of the clones from the libraries with the probes $(\mathrm{TC})_{13},(\mathrm{GATA})_{4},(\mathrm{CAC})_{10}$ and $(\mathrm{TGAG})_{8}$ no microsatellite sequences were observed. Therefore, only in the library enriched with the probe (TCA) ${ }_{10}$ was possible to design primers.

According to Lagercrantz et al. (1993) and Wang et al. (1994), plant microsatellite are about five times less abundant than in humans, where there is a microsatellite (bigger than $20 \mathrm{bp}$ ) at each $\mathrm{Kb}$. In the monocots a microsatellite is expected at each $65 \mathrm{~Kb}$, while in the dicots there is one SSR at each $21 \mathrm{~Kb}$. The dinucleotide AT/TA is the most common, followed by AA/TT and GA/CT. The motif GT/CA is significantly less abundant in plants. The non-occurrence of microsatellites in the other enriched libraries could suggest a probable absence of the required sequences in the papaya genome.

Parasnis et al. (1999) also observed the non occurrence of the microsatellite sequences (GAA) 6 , (TG) ${ }_{10},(\mathrm{CAC})_{5},(\mathrm{GGAT})_{4}$ and (GACA) in the genome of 6 papaya cultivars by Southern Blotting. However, when using the probe (GATA) they obtained a $5 \mathrm{~Kb}$ band, specific for male plants, indicating a divergence between the $\mathrm{X}$ and $\mathrm{Y}$ chromosomes of papaya.

Which are shown in Table 2. These results were very productive when compared with those of other researcher who worked without enrichment of the libraries, such as Hicks et al. (1998), working on Pinus contorta, from a total of 180.000 clones only 20 microsatellite sequences were found. Cordeiro et al. (2001), in a sugar cane (Saccharum spp.) library, from 8678 sequences found 250 microsatellite sequences. From 21 pairs of primers designed, 17 were polymorphic.

In Table 2, the motifs flanked by the designed primers can be observed. The name of each detected region was done by the nomenclature logic: use of the cultivar initials, followed by the number of clone used. Some clones containing microsatellite regions could not be used for the design of primers either because there were no flanking regions of adequate size, or because they had a small number of repetitions of the motifs. Cordeiro et al. (2000) analyzed in sugar cane varieties, the potential of microsatellite repetitions, the abundance, variability and the ability to detect polymorphisms. For that, they build a library enriched with microsatellites, that is, beginning from a microsatellite consortium. Of the 798 sequenced clones, 457 inserts containing microsatellites were observed. About $84 \%$ of the microsatellite contained repetitions with dinucleotides and trinucleotides repeated 15 and 13 times, respectively. One hundred pairs of microsatellite primers were designed and tested in 5 cultivars.

To our advantage, in the present study, microsatellites with mixed motifs were found, although only the probe (TCA) ${ }_{10}$ had been used. This can be explained since these non-expected motifs were mostly in tandem with the motif searched by the probe used. A similar situation was found by Hicks et al. (1998) who found (AT) motifs in Pinus contorta microsatellites during a search with the motif $(\mathrm{GA})_{\mathrm{n}}$.

All the designed primers were tested by PCR in the female and hermaphrodite plants of the cultivars Sunrise Solo, Improved Sunrise Solo cv. 72/12 e Baixinho de Santa Amália. When the reaction products were tested in a high resolution 3.5\% Metaphor agarose gel (Figure 1), what was found was a pattern of a single band for 31 pairs of primers. When the same reactions were visualized in $8 \%$ polyacrilamide gels with or without denaturing agent, and in a polyacrilamide gel in a manual sequencing plate again, a profile of a single band was found.

In any of the gels evaluated, even when considering the higher resolution power of the polyacrilamide in relation to the agarose gel. The primer S36 (Figure 2) yielded 2 bands, that is, it was capable of showing the 2 alleles; however, this primer could not differentiate the two sex forms. It is important to note that the materials used to test this primer were homogeneous, that is, the material originated from female and hermaphrodite plants of the most well known cultivars of the group Solo. These materials have a narrow genetic base, as a function of the several crossings since its introduction in the country. Thus, if primer 
TABLE 2 - Primers designed from the sequences flanking the microsatellite regions of Carica papaya cv. Sunrise Solo.

\begin{tabular}{|c|c|c|c|c|}
\hline Primer & $\mathbf{T}^{0} \mathrm{C}$ & Size & SSR Motif & Primer sequence $\left(5^{\prime} \rightarrow 3^{\prime}\right)$ \\
\hline S216 & 47 & 122 & $(\mathrm{TCA})_{13}(\mathrm{CCA})_{6}$ & $\begin{array}{l}\text { F: 5'AAgTCTCTCAAgATgTCAgC 3' } \\
\text { R: 5' TAgTgCAgAggTATggATAg 3' }\end{array}$ \\
\hline S338 & 46 & 101 & $(\mathrm{GAT})_{9}$ & $\begin{array}{l}\text { F: 5' AAggTgCggTTggTATAg 3' } \\
\text { R: 5' CTTCCTCCTCTCACCATC } 3\end{array}$ \\
\hline S285 & 47 & 329 & $(\mathrm{GAT})_{3}$ & $\begin{array}{l}\text { F: 5' AATgTgTgAgAATAggTTgg 3', } \\
\text { R: 5' CAATCTATCCTCCTCATgTA 3' }\end{array}$ \\
\hline S100 & 47 & 139 & $(\mathrm{TGA})_{4}$ & $\begin{array}{l}\text { F: 5' TACTTgTgATgAATggTgCT 3', } \\
\text { R: 5' CACCAATCTAATCCATTgCT 3' }\end{array}$ \\
\hline S36 & 47 & 170 & $(\mathrm{TT})_{5}(\mathrm{GTT})_{3}$ & $\begin{array}{l}\text { F: 5' CAAgCgTTAATCACAAgg 3' } \\
\text { R: 5' TggTg gTgATgATgATTgg 3' }\end{array}$ \\
\hline S401 & 48 & 159 & $(\mathrm{GAT})_{8}(\mathrm{GAG})_{2}$ & $\begin{array}{l}\text { F: 5' TCTgTCgACgAgACTATCAT 3' } \\
\text { R: 5' TCTCTATTCATCTTCTCCgT } 3\end{array}$ \\
\hline S414 & 47 & 259 & $(\mathrm{AC})_{7}$ & $\begin{array}{l}\text { F: 5' CATTCTTAgCCAgATgATgT 3' } \\
\text { R: 5' ATTgCATgTACACATACCgT 3' }\end{array}$ \\
\hline S422 & 44 & 84 & $(\mathrm{GAT})_{5}$ & $\begin{array}{l}\text { F: 5' ACgCATCACACgTATATCTA 3', } \\
\text { R: 5' ATAACCTCgCTACATC CTCT 3, }\end{array}$ \\
\hline $\mathbf{S 4 2 3}$ & 48 & 258 & $(\mathrm{GT})_{4}(\mathrm{TG})_{2}$ & $\begin{array}{l}\text { F: 5' TCTTgATgAAgTAATggCAg 3' } \\
\text { R: 5' ATTAACCgAgATTCAgAAgC 3' }\end{array}$ \\
\hline S432 & 45 & 76 & $(\mathrm{GAT})_{8}$ & $\begin{array}{l}\text { F: 5' CTgATgATgATgACgATgAT 3' } \\
\text { R: 5' gTTgACCTACTgCTgTTgCT 3' }\end{array}$ \\
\hline S445 & 45 & 160 & $(\mathrm{TA})_{6}$ & $\begin{array}{l}\text { F: 5' CAggAATCgACAgAgAATAA 3' } \\
\text { R: 5' ggTgTCgAATCAAgTAAggA 3' }\end{array}$ \\
\hline S446 & 49 & 94 & $(\mathrm{GAT})_{3}$ & $\begin{array}{l}\text { F: 5' gAggTgTACAAgCCACAgAT 3', } \\
\text { R: 5' gCTTCATTCTTAATTCgCTC 3' }\end{array}$ \\
\hline S469 & 43 & 181 & $\begin{array}{l}(\mathrm{TAA})_{2}(\mathrm{TTA})_{2} \\
(\mathrm{ATT})_{3}\end{array}$ & $\begin{array}{l}\text { F: 5' CTACTgATggAACTAgACAA 3', } \\
\text { R: 5' AACATCATACATgCAgACAC 3' }\end{array}$ \\
\hline S473 & 47 & 160 & $(\mathrm{TA})_{4}$ & $\begin{array}{l}\text { F: 5' CATACTCAggACATTATgCT 3' } \\
\text { R: 5' TgCgATACTACTgTCACTgg 3' }\end{array}$ \\
\hline S475 & 46 & 95 & $(\mathrm{GTT})_{4}(\mathrm{GAT})_{6}$ & $\begin{array}{l}\text { F: 5' AACTgTgAgAgACTTggTgg 3' } \\
\text { R: 5' TCATCATCATCATCgTCATC 3' }\end{array}$ \\
\hline S478 & 47 & 211 & $(\mathrm{AT})_{3}(\mathrm{TA})_{3}$ & $\begin{array}{l}\text { F: 5' ATggCgATgAATCAAgTAAC 3' } \\
\text { R: 5' ggCATATATCTTCCAAgTgT 3' }\end{array}$ \\
\hline S480 & 49 & 236 & $\begin{array}{l}(\mathrm{GAT})_{2}(\mathrm{GCC})_{2} \\
(\mathrm{GCG})\end{array}$ & $\begin{array}{l}\text { F: 5' AgCTACATTACAATACCTCg 3' } \\
\text { R: 5' CAgCTCTgACCATgATT ACg 3' }\end{array}$ \\
\hline S489 & 45 & 114 & $\begin{array}{l}(\mathrm{GAT})_{6}(\mathrm{GTT})_{2} \\
(\mathrm{TGT})(\mathrm{GTG})\end{array}$ & $\begin{array}{l}\text { F: 5' ATAgTCTTAgTgATTCgCAg 3', } \\
\text { R: 5'TCAACTCAACCACACAAgTA 3' }\end{array}$ \\
\hline S463 & 45 & 83 & $\begin{array}{l}(\mathrm{TGG})_{2}(\mathrm{GTG})_{2} \\
(\mathrm{GTT})(\mathrm{TTG})\end{array}$ & $\begin{array}{l}\text { F: 5' TTgTgTTgAgATggTgATgT 3' } \\
\text { R: 5' TTCCTATTAACACCTCATCC 3, }\end{array}$ \\
\hline S509 & 46 & 166 & $(\mathrm{GAA})_{3}$ & $\begin{array}{l}\text { F: 5' gAggTATTCTgAgAgAgCTg 3' } \\
\text { R: 5' TACTgACCTCTTCTTgTTgT 3' }\end{array}$ \\
\hline S513 & 47 & 205 & $(\mathrm{GAT})_{4}$ & $\begin{array}{l}\text { F: 5' ATTCgATgTTCTCTCACACC 3' } \\
\text { R: 5' CAgTTATggAATACATCACC 3' }\end{array}$ \\
\hline S516 & 47 & 156 & $(\mathrm{GAT})_{3}$ & $\begin{array}{l}\text { F: 5' ACCTCTgTTCTgCACAAgTC 3', } \\
\text { R:5' TCCAATAACACCATCAACTC } 3 \text {, }\end{array}$ \\
\hline S521 & 46 & 115 & $(\mathrm{GAT})_{8}$ & $\begin{array}{l}\text { F: 5' gATACAgAAgCTATTgCTgC 3', } \\
\text { R: 5' AATCATCC ATATCTTCCTCC 3' }\end{array}$ \\
\hline S548 & 42 & 128 & $(\mathrm{GAT})_{5}$ & $\begin{array}{l}\text { F: 5' gTACTCgTTAATTAgCCAAg 3' } \\
\text { R: 5' CAAgCTCTCAATgACTCTTC 3' }\end{array}$ \\
\hline S552 & 44 & 112 & $(\mathrm{GAT})_{4}$ & $\begin{array}{l}\text { F: 5' AACAAgTggAACTCCTATAC 3' } \\
\text { R: 5' CAATggAACTTCTgCTACTA 3' }\end{array}$ \\
\hline S556 & 47 & 171 & $(\mathrm{GAT})_{3}$ & $\begin{array}{l}\text { F: 5' ATgAATgCTAAggATTgTgg 3' } \\
\text { R: 5' ggACTCACTACCTTCTgACC } 3\end{array}$ \\
\hline S5 & 50 & 182 & $(\mathrm{GGT})_{12}(\mathrm{GAT})_{14}$ & $\begin{array}{l}\text { F: 5' gTgATgATgATgATggTggT 3' } \\
\text { R: 5'AATACTCAAgCTATgCATCC 3' }\end{array}$ \\
\hline S6 & 51 & 265 & $(\mathrm{TCA})_{5}$ & F: 5’ ATCCTCTAgTCATggTggTG 3' \\
\hline
\end{tabular}

$\mathrm{T}^{\circ} \mathrm{C}$ - annealing temperature; Size - size in base pairs;

S36 had been tested in heterogeneous materials, maybe polymorphisms could have been detected.

Keeping in mind that a sub-library was made, and several microsatellite primers were designed for Carica papaya, these could be tested in the investigation of other characteristics in segregating populations of this species and related species, germplasm analysis, identification of cultivars, parent evolution and molecular markers for the assisted plant breeding programs. Among these characteristics, the ones with most agricultural interest are those related to the genes for dwarf plants, resistance to the mosaic virus, and early and highly productive plants. 


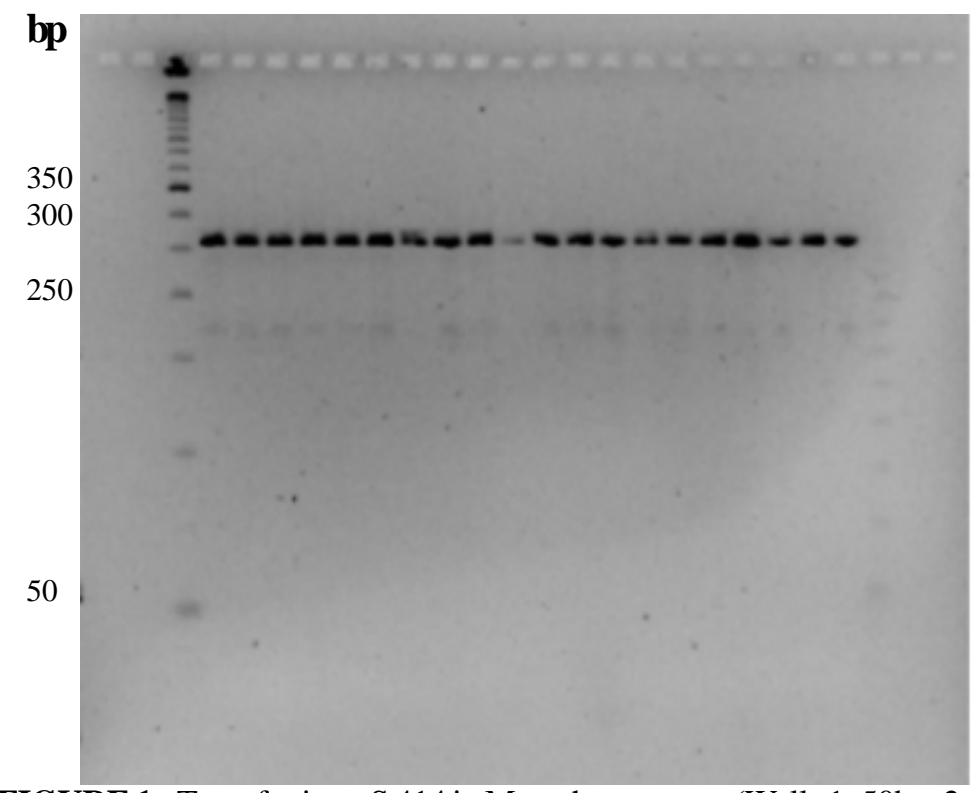

FIGURE 1 - Test of primer S 414 in Metaphor agarose (Wells 1: 50bp, 211: hermaphrodite plants; 12-21: female plants cv. Baixinho de Santa Amália).

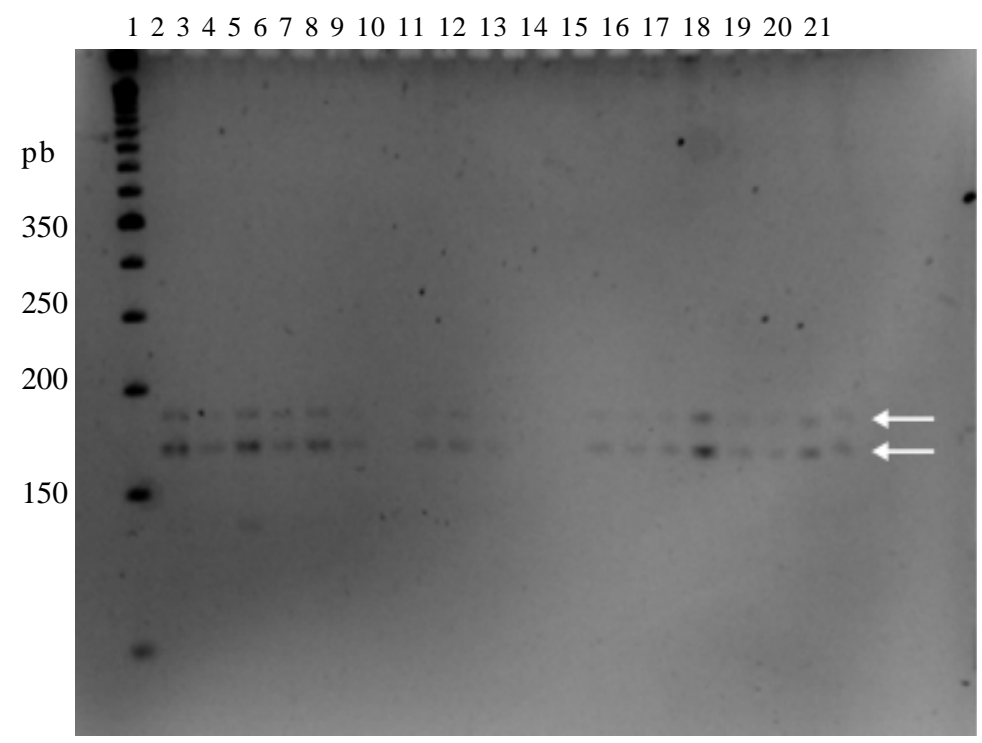

FIGURE 2 - Amplification of 20 samples of Carica papaya cv. Sunrise Solo with the primer S36 in Metaphor agarose (Wells 1: 50bp, 2-11: hermaphrodite plants; 12-21: female plants). The arrows show the occurrence of 2 alleles.

\section{CONCLUSIONS}

1) About 1500 clones were obtained for the probe (TCA) library, which were sequenced and analyzed in the search for microsatellite sequences. This library allowed for the design of 32 pairs of primers.

2) Sequencing this library demonstrated that in the Carica papaya genome there are categories of different microsatellites, such as $(\mathrm{GAT})_{\mathrm{n}}$; $(\mathrm{TGA})_{\mathrm{n}}$; $(\mathrm{TCA})_{\mathrm{n}}$; mixed motifs $(\mathrm{GAT})_{8}(\mathrm{GAG})_{2}$, $(\mathrm{GAT})_{11}(\mathrm{GGT})_{5},(\mathrm{GGT})_{12}(\mathrm{GAT})_{14}$ and dinucleotides such as $(\mathrm{AC})_{7}$, $(\mathrm{GT})_{4}(\mathrm{TG})_{2}$.

3) There were no differences on the behavior of the profiles for the two sex forms of the three cultivars studied

\section{REFERENCES}

AGRIANUAL 2000: anuário da agricultura brasileira. São Paulo: FNP Consultoria e Comércio, 2001.

CORDEIRO, G. M., et al. Microsatellite markers from sugarcane (Saccharum spp.) ESTs cross transferable to erianthus and sorghum. Plant Sciencie, Columbus, v.160, p.1115-1123, 2001.

CORDEIRO, G. M., TAYLOR, G. O., HENRY, R. J. Characterisation of microsatellite markers from sugarcane (Saccharum spp.), a highly polyploid species. Plant Science, Lucknow, v.155, p.161-168, 2000.

HICKS, M. et al. The development of RAPD and microsatellite markers in lodgepole pine (Pinus contorta var. latifolia). Genome, Ottawa, v.41, n.6, p.797-805, 1998.

LAGERCRANTZ, V., ELLEGREN, H., ANDERSON, L. The abundance of various polymorphic microsatellite motifs differs between plants vertebrates. Nucleic Acids Research, Oxford, v.21, n.5, p.1111$1115,1993$.

MANIATIS, T.; FRITSCH, E.F.; SAMBROOK, L. Molecular cloning: a laboratory manual. New York: Cold Spring Harbor Laboratory Press, 1989.

MENDES, L.G.; DANTAS, J.L.L.; MORALES, C.F.G. (Ed.). Mamão no Brasil. Cruz das Almas: EAUFBA/EMBRAPA-CNPMF, 1996. $179 \mathrm{p}$.

PARASNIS, A. S. et al. Microsatellite (GATA) revels sex-especific differences in papaya. Theoretical. Applied. Genetics, Berlim, v.99, p.1047-1052, 1999.

PINTO, L. R. et al. Isoenzimas e Microsatélites em Plantas. Biotecnologia Ciência \& Desenvolvimento, Brasília, n. 20, p.1619, 2001.

SAGHAI-MAROOF, M.A. et al. Ribosomal DNA spacer-length polymorphisms in barley: mendelian inheritance, chromosomal location, and population dynamics. Proceedings of the National Academy of Science USA, Allahabad, v.81, p.8014-8018, 1984.

SHARON, D. et al. Application of DNA fingerprints for identification and genetic analysis of Carica papaya and other Carica species. Euphytica, Wageninger, v.62, p.119-126, 1992.

WANG, Z. et al. Survey pf plant short tandem DNA repeats. Theoretical.Applied. Genetics, Berlin, v.88, p.1-6, 1994. 